Bangladesh J. Bot. 49(4): 1111-1117, 2020 (December)

\title{
EFFECTS OF ORGANIC MANURES AND BIO-FERTILIZERS ON GROWTH, FLOWERING AND YIELD OF CHINA ASTER (CALLISTEPHUS CHINENSIS L. NEES VAR. KAMINI)
}

\author{
Bidanchi S Marak, Sunil Kumar*1 and Kalkame CH Momin ${ }^{1}$ \\ Department of Horticulture, North Eastern Hill University, Tura Campus, \\ Tura-794 002, West Garo Hills district, Meghalaya, India
}

Keywords: China aster, Azospirillum, PSB, Vermicompost, FYM

\begin{abstract}
Effects of organic manures and bio-fertilizers on growth, flowering and yield of China aster (Callistephus chinensis) var. kamini was investigated. The experiment with 12 treatment combinations comprising of FYM, vermicompost and bio-fertilizers viz., phosphate solublising bacteria (PSB) and Azospirillum was conducted. All the treatment combinations showed significant response in vegetative, flowering and yield characters during the entire investigation. The treatment combinations of Azospirillum + PSB + vermicompost $+50 \%$ RDF was found to be promising for maximum plant height $(63.97 \mathrm{~cm})$, plant spread $(21.50 \mathrm{~cm})$, stem girth $(15.47 \mathrm{~mm})$, number of primary branches per plants $(12.33)$, number of secondary branches per plants (22.14), enhanced flower bud emergence (73.33 days), stalk length $(32.20 \mathrm{~cm})$, number of flowers per plant (24.35), flower diameter $(46.18 \mathrm{~mm})$, prolonged flower duration (23.05 days), flower yield (18.87 q/ha) and seed yield ( $2.44 \mathrm{q} / \mathrm{ha})$ were on par with Azospirillum + PSB + FYM $+50 \%$ RDF.
\end{abstract}

\section{Introduction}

China aster (Callistephus chinensis L. cv. kamini), a member of Asteraceae, is one of the important commercial flower crops. It is hardy, free blooming and annual flower. The wide spectrum of forms, colours (pink, blue, violet and white) and their long vase life have made it as popular cut flower. Its cultivation is becoming popular around the cities for its extensive use in making bouquets, buttonholes and garlands. In ornamental gardening, it finds a place as bedding plant, edging pot plant and herbaceous border.

Nutritional management through organic manure is helpful for enhancing yield, quality of flowers and vase life in marigold (Kumar and Sharma 2013). Generally, China aster responds very well to the application of inorganic and organic fertilizers. Bio-fertilizer usually consists of live or latent cells of microorganisms which include biological nitrogen fixers, P-solubilizing, mineralization of nitrogen and transformation of several elements into available forms. VAM, Azotobacter, Azospirillum and phosphate solubilizing bacteria are commonly applied biofertilizers in horticultural crops (Zaredost et al. 2014). Use of bio-fertilizers reduces per unit consumption of inorganic fertilizers and increases the quality and quantity of flowers (Syamal et al. 2006). Organic and bio-fertilizer like vermicompost, farm yard manure Azotobacter and Azospirillum play an important role in improving the plant growth because of major constituent in chlorophyll, protein and amino acids, resulted in increased production of green leaves. Favorable effects of organic fertilizers on growth and flower production in China aster were emphasized by many workers (Ravindra et al. 2013, Bohra et al. 2016). Hence, the present study was carried out to investigate the performance of bio-fertilizers on growth, flowering and yield of China aster (Callistephus chinensis L.) cv. kamini.

*Author for correspondence:<sunu159@gmail.com>. ${ }^{1}$ Department of Floriculture \& Landscape Architecture, College of Horticulture \& Forestry, Central Agricultural University, Pasighat-791 102, East Siang district, Arunachal Pradesh, India. 


\section{Materials and Methods}

A field experiment on response of bio-fertilizers on growth, flowering and yield of China aster at Instructional farm, Department of Horticulture, North-Eastern Hill University, Tura campus, Chasingre, West Garo Hills district, Tura-794002, Meghalaya, India was conducted during September, 2017 to April, 2018. Twelve treatments viz., Control (100\% RDF), Azospirillum $+75 \%$ RD 'N' + 100\% RD 'P' and 'K', PSB + 75\% RD 'P' + 100\% RD 'N' and ' $\mathrm{K}$ ', $\mathrm{FYM}+50 \% \mathrm{RDF}, \mathrm{VC}+50 \% \mathrm{RDF}$, Azospirillum $+\mathrm{FYM}+50 \% \mathrm{RDF}$, Azospirillum $+\mathrm{VC}+50 \%$ $\mathrm{RDF}, \mathrm{PSB}+\mathrm{FYM}+50 \% \mathrm{RDF}, \mathrm{PSB}+\mathrm{VC}+50 \% \mathrm{RDF}$, Azospirillum $+\mathrm{PSB}+50 \% \mathrm{RD}$ 'N' and 'P' + $100 \%$ RD 'K', Azospirillum + PSB + FYM + 50\% RDF and Azospirillum + PSB + VC + $50 \%$ RDF were compared to find out suitable dose of organic fertilizers under agro-climatic conditions of Tura. Recommended dose of nitrogen $(180 \mathrm{~kg} / \mathrm{ha})$, phosphorous $(120 \mathrm{~kg} / \mathrm{ha})$ and potassium $(60 \mathrm{~kg} / \mathrm{ha})$ in the form of urea, single super phosphate (SSP) and murate of potash (MOP), respectively, were applied into the soil before transplanting. The experiment was laid out in RCBD with three replications. Uniform size $(10-15 \mathrm{~cm})$ of China aster seedlings cv. kamini was transplanted on raised beds at spacing $30 \times 20 \mathrm{~cm}$. The observations on vegetative growth, flowering and yield characters were recorded and analysed statistically as suggested by Panse and Sukhatme (1995).

\section{Results and Discussion}

Significant response of organic manures and bio-fertilizers on growth characters is presented in Table 1. Maximum plant height $(63.97 \mathrm{~cm})$ was associated with application of Azospirillum + $\mathrm{PSB}+\mathrm{VC}+50 \% \mathrm{RDF}$ followed by Azospirillum + PSB + FYM + 50\% RDF $(60.33 \mathrm{~cm})$ and PSB $+\mathrm{VC}+50 \% \mathrm{RDF}(50.57 \mathrm{~cm})$. The increase in plant height with combination of organic manure and bio-fertilizers might be due to the increase in transport of metabolites and rate of photosynthesis in the plant, which enables the plant to have quick and better upward vegetative growth. Combination of organic manure and bio-fertilizers proved to be the best for attaining the maximum plant height (Keisam et al. 2014) in gladiolus.

The highest plant spread $(21.50 \mathrm{~cm})$ was noticed with the application of Azospirillum + PSB + $\mathrm{VC}+50 \% \mathrm{RDF}$ followed by PSB $+\mathrm{VC}+50 \% \mathrm{RDF}(19.43 \mathrm{~cm})$ and Azospirillum $+\mathrm{VC}+50 \%$ RDF $(17.83 \mathrm{~cm})$. However, the plant spread with application of Azospirillum + PSB $+\mathrm{VC}+50 \%$ RDF $(21.50 \mathrm{~cm})$ was on par with Azospirillum + PSB + FYM + 50\% RDF $(21.11 \mathrm{~cm})$. Maximum plant spread obtained might be due to formation of new cells in meristem and increased in size resulted more production of cells (Barad et al. 2015). Lolasuramath (2014) reported that the maximum plant height and plant spread in China aster cv. poornima were obtained with organic manure and bio-fertilizers application. Maximum stem girth showed by Azospirillum + PSB + VC + 50\% RDF $(15.47 \mathrm{~cm})$ was on par with Azospirillum + PSB + FYM + 50\% RDF $(15.40 \mathrm{~cm})$, while, minimum stem girth was observed in control $(13.13 \mathrm{~cm})$. Ravindra et al. (2013) stated that combination of organic manures and bio-fertilizers along with inorganic fertilizers resulted in the tallest plant, maximum number of branches and thickest stem. Increased number of primary branch and secondary branch was observed in the plot which received Azospirillum $+\mathrm{PSB}+\mathrm{VC}+$ $50 \% \operatorname{RDF}(22.14,12.33)$ which was on par with the Azospirillum + PSB + FYM + 50\% RDF $(22.00,11.67)$ and the Azospirillum + PSB + 50\% RD 'N' and 'P' + 100\% RD 'K' $(21.67,11.67)$. Significant response in vegetative growth, flowering characters and quality parameters in China aster cv. kamini was also observed by Kumar et al. (2016), Tomar et al. (2013) in marigold cv. dwarf orange.

Significant responses of organic manures and bio-fertilizers on flowering characters is presented in Table 2. Earliness in flower bud initiation showed by Azospirillum + PSB + VC + 
50\% RDF (73.33 days) followed by Azospirillum + PSB + 50\% RD 'N' and 'P' + 100\% RD 'K' (83.00 days), but was on par with $\mathrm{VC}+50 \% \mathrm{RDF}$ (76.33 days). The delayed flowering was observed in control (93.00 days). Earliness in flower bud initiation with organic manure and biofertilizer applications was also observed by Keisam et al. (2014) in gladiolus, Kumari et al. (2014) in chrysanthemum and Zaredost et al. (2014) in marigold.

Table 1. Effect of organic manure and bio-fertilizers on vegetative growth of China aster at Tura.

\begin{tabular}{llllll}
\hline Treatments & $\begin{array}{l}\text { Plant } \\
\text { height } \\
(\mathrm{cm})\end{array}$ & $\begin{array}{l}\text { Plant } \\
\text { spread } \\
(\mathrm{cm})\end{array}$ & $\begin{array}{l}\text { Stem } \\
\text { girth } \\
(\mathrm{mm})\end{array}$ & $\begin{array}{l}\text { No. of } \\
\text { primary } \\
\text { branch }\end{array}$ & $\begin{array}{l}\text { Number of } \\
\text { secondary } \\
\text { branch }\end{array}$ \\
\hline $\mathrm{T}_{1}$ control (100\% RDF) & 46.20 & 15.40 & 13.13 & 14.33 & 11.08 \\
$\mathrm{~T}_{2}$ (Azospirillum + 75\% RDF 'N' + 100\% RD 'P' & 48.10 & 16.97 & 14.43 & 15.67 & 11.00 \\
and 'K') & & & & & \\
$\mathrm{T}_{3}(\mathrm{PSB}+75 \% \mathrm{RD}$ 'P' + 100\% RD 'N' and 'K') & 45.07 & 15.13 & 13.20 & 13.33 & 11.18 \\
$\mathrm{~T}_{4}(\mathrm{FYM}+50 \% \mathrm{RDF})$ & 49.43 & 16.07 & 15.17 & 20.33 & 12.33 \\
$\mathrm{~T}_{5}(\mathrm{VC}+50 \% \mathrm{RDF})$ & 54.50 & 18.53 & 15.30 & 18.00 & 11.33 \\
$\mathrm{~T}_{6}$ (Azospirillum + FYM + 50\% RDF) & 54.67 & 20.43 & 15.16 & 16.33 & 12.00 \\
$\mathrm{~T}_{7}$ (Azospirillum + VC + 50\% RDF) & 49.47 & 17.83 & 14.82 & 17.00 & 11.67 \\
$\mathrm{~T}_{8}(\mathrm{PSB}+\mathrm{FYM}+50 \% \mathrm{RDF})$ & 52.17 & 20.30 & 15.32 & 18.33 & 12.00 \\
$\mathrm{~T}_{9}(\mathrm{PSB}+\mathrm{VC}+50 \% \mathrm{RDF})$ & 50.57 & 19.43 & 15.18 & 19.00 & 11.67 \\
$\mathrm{~T}_{10}$ (Azospirillum + PSB + 50\% RD 'N' and 'P' + & 59.83 & 20.78 & 14.84 & 21.67 & 11.67 \\
$100 \%$ RD 'K' & & & & & \\
$\mathrm{T}_{11}($ Azospirillum + PSB + FYM + 50\% RDF) & 60.33 & 21.11 & 15.40 & 22.00 & 11.67 \\
$\mathrm{~T}_{12}$ (Azospirillum + PSB + VC + 50\% RDF) & 63.97 & 21.50 & 15.47 & 22.14 & 12.33 \\
$\mathrm{C.D}(\mathrm{p}=0.05)$ & 2.01 & 1.46 & 0.86 & 1.09 & 0.88 \\
$\mathrm{CV}$ (\%) & 6.63 & 6.31 & 5.24 & 5.79 & 6.77 \\
\hline
\end{tabular}

Minimum days for colour break stage (83.74 days) was noticed under treatment with Azospirillum + PSB + VC + 50\% RDF $(83.74 \mathrm{~cm})$ followed by FYM + 50\% RDF (87.20 days) but was on par with PSB + FYM + 50\% RDF (84.40 days). While, reduced number of days for bloom was associated with Azospirillum + PSB + VC + 50\% RDF (91.58 days) which was on par with $\mathrm{VC}+50 \% \mathrm{RDF}$ (97.20 days) and Azospirillum + VC + 50\% RDF (97.40 days). Reduction in days taken for flowering was also reported by Pandey et al. (2010) in chrysanthemum and Kumar et al. (2015) in Dendrobium orchid. However, highest flower stalk length $(34.00 \mathrm{~cm})$ was noticed with Azospirillum + PSB + VC + 50\% RDF $(32.20 \mathrm{~cm})$ which was on par with Azospirillum + PSB + $50 \% \mathrm{RD}$ 'N' and 'P' + 100\% RD 'K' $(31.50 \mathrm{~cm})$ and Azospirillum + PSB + FYM + 50\% RDF $(31.51 \mathrm{~cm})$. The lowest flower stalk length was observed in control $(27.99 \mathrm{~cm})$. These results corroborate with the findings of Dalve et al. (2009) where it was revealed that spike length and rachis length in gladiolus significantly increased with the application of organic manures and biofertilizers.

The maximum flower diameter $(46.18 \mathrm{~cm})$ was associated with Azospirillum $+\mathrm{PSB}+\mathrm{VC}+$ $50 \%$ RDF (46.18 mm) which was on par with, Azospirillum + PSB + FYM + 50\% RDF (46.14 $\mathrm{mm}$ ) and Azospirillum + PSB + 50\% RD 'N' and 'P' + 100\% RD ' $\mathrm{K}$ ' (45.91 mm), whereas, minimum flower diameter was noticed under control $(17.79 \mathrm{~cm})$. The beneficial effect on earliness 


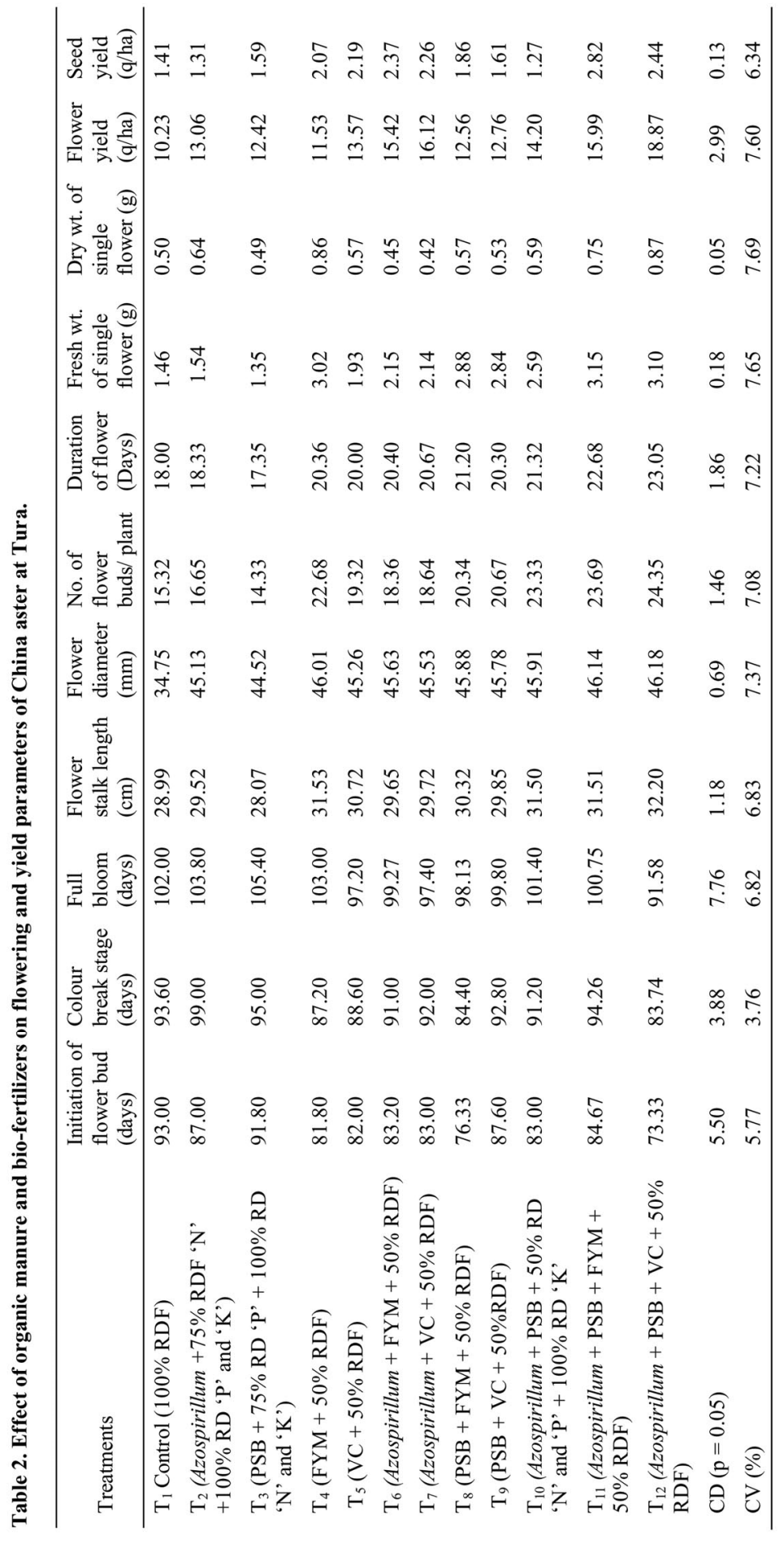


in flower bud initiation, improving flower stalk length, large sized flower and number of flower buds might be due to early breaking of apical dominance followed by easy and better translocation of nutrients to the flowers, better plant growth by the increased availability of nutrients and accelerated mobility of photosynthates from source to sink as influenced by the growth hormones released or synthesized from organic manures and bio-fertilizers. These results are in accordance with the findings of Panchal et al. (2010) in chrysanthemum, Sharma et al. (2009) in China aster and Deshmukh et al. (2008) in gaillardia.

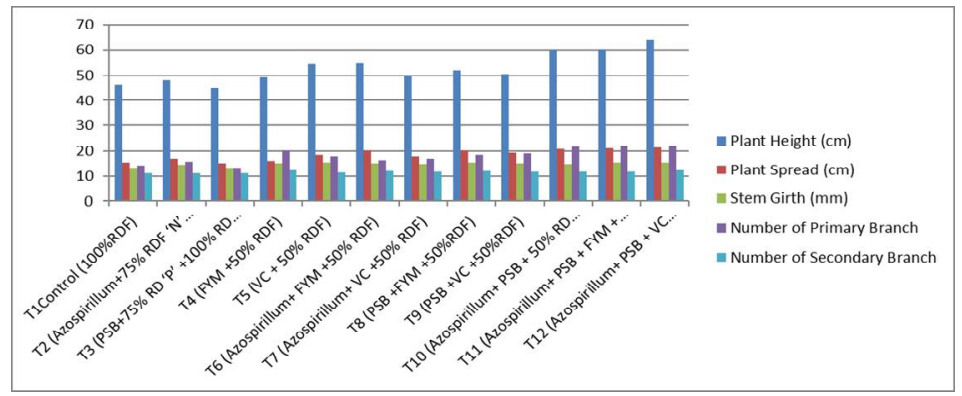

Fig.1. Effect of bio-fertilizers on vegetative growth of China aster.

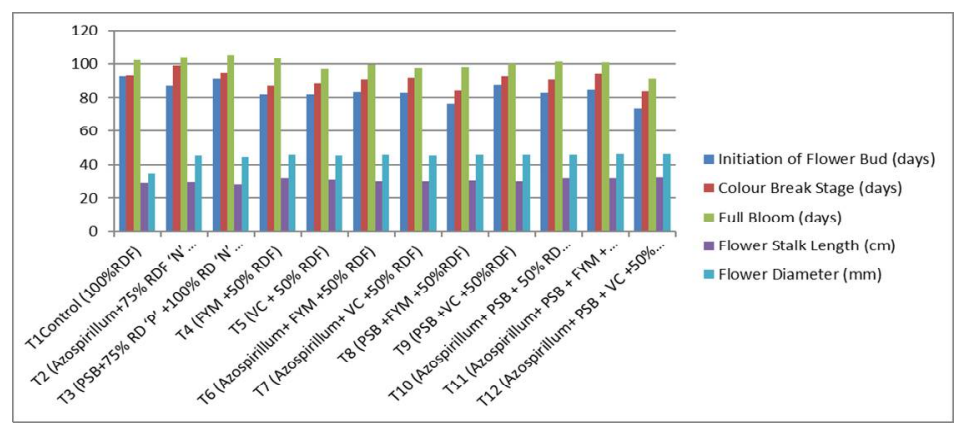

Fig. 2. Effect of bio-fertilizers on flowering parameters of China aster.

Use of Azospirillum + PSB + VC $+50 \%$ RDF produced highest number of flower buds per plant (24.35) which was on par with Azospirillum + PSB + FYM + 50\% RDF (23.69) and Azospirillum + PSB + 50\% RD 'N' and 'P' + 100\% RD 'K' (23.33). Similar results were noticed by Ali et al. (2014) who stated that application of biofertilizers resulted in the maximum number of flowers in gladiolus. Keisam et al. (2014) also reported the maximum length of flower stalk, number of flowers per plant and flower weight in gladiolus, obtained with the application of organic nutrients.

Prolonged duration of flowering recorded with Azospirillum + PSB + VC $+50 \%$ RDF produced highest number of flower buds per plant (23.05 days) which was on par with Azospirillum + PSB + FYM + 50\% RDF (22.68 days) and Azospirillum + PSB + 50\% RD 'N' and 'P' $+100 \%$ RD 'K' (21.32 days). Use of Azospirillum + PSB + FYM + 50\% RDF showed increased fresh weight of single flower $(3.15 \mathrm{~g}$ ) which was on par with Azospirillum + PSB + VC $+50 \% \operatorname{RDF}(3.10 \mathrm{~g})$ and followed by Azospirillum + PSB + 50\% RD ' $\mathrm{N}$ ' and ' $\mathrm{P}$ ' + $100 \% \mathrm{RD}$ ' $\mathrm{K}$ ' $(2.59 \mathrm{~g})$. Hadwani et al. 2013 stated that application of integrated nutrients resulted in the longest flowering duration. Maximum number of flowers and increased fresh weight might be due to the direct response of organic fertilization which may promote cell proliferation efficiently. Moreover, 
Azospirillum $+\mathrm{PSB}+\mathrm{VC}+50 \% \mathrm{RDF}$ recorded maximum dry weight of single flower $(0.87 \mathrm{~g})$ followed by Azospirillum + PSB + FYM + 50\% RDF $(0.75 \mathrm{~g})$ and Azospirillum + PSB + 50\% RD ' $\mathrm{N}$ ' and ' $\mathrm{P}$ ' $+100 \% \mathrm{RD}$ ' $\mathrm{K}$ ' $(0.59 \mathrm{~g})$. The minimum dry weight of single flower was associated with control $(0.50 \mathrm{~g})$. The increase in dry weight might be due to luxurious vegetative growth in terms of plant height, stem girth and number of branches. These results corroborate with the findings of Panchal et al. (2010) in chrysanthemum and Ali et al. (2014) in gladiolus which revealed that application of organic nutrients increased significantly fresh and dry weights. Enhanced flower yield was noted with Azospirillum + PSB + VC $+50 \%$ RDF $(18.87 \mathrm{q} / \mathrm{ha})$ followed by Azospirillum + VC $+50 \%$ RDF $(16.12$ q/ha) which was on par with Azospirillum + PSB + FYM + 50\% RDF (15.99q/ha), whilst lowest flower yield was associated with control (10.23 q/ha). Nevertheless, maximum seed yield was obtained from Azospirillum + PSB + FYM + $50 \% \mathrm{RDF}(2.82 \mathrm{q} / \mathrm{ha})$ followed by Azospirillum + PSB + VC +50\% RDF (2.44 q/ha) which was on par with Azospirillum + FYM + 50\% RDF (2.37 q/ha). These results are in close conformity with the findings of Thumar et al. (2013) in marigold and Sharma et al. (2009) in China aster which revealed that application of organic manures and bio-fertilizers increased significantly flower yield per plant and flower yield per hectare.

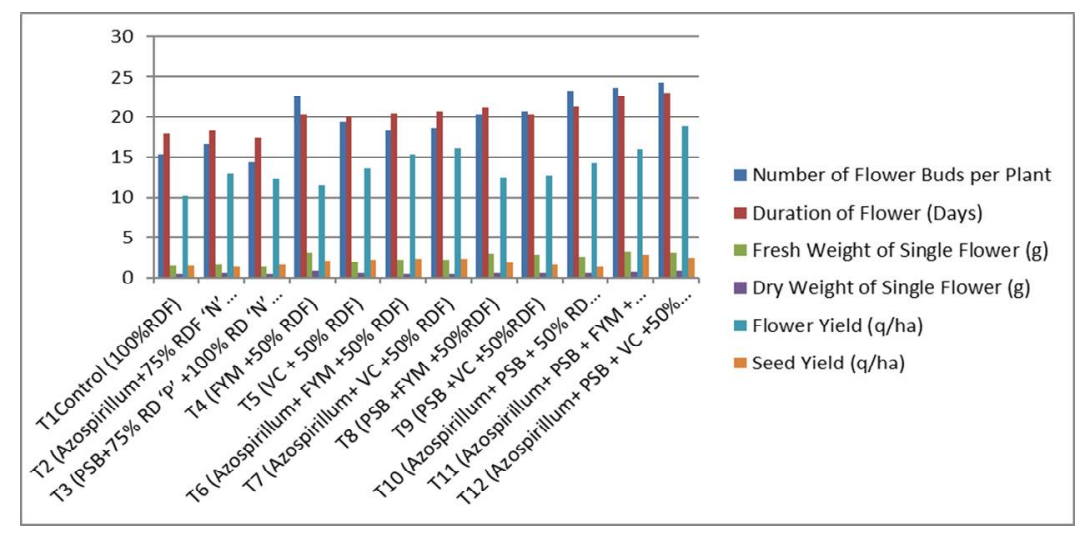

Fig. 3. Effect of bio-fertilizers on yield parameters of China aster.

Thus, the application of Azospirillum $+\mathrm{PSB}+\mathrm{VC}+50 \% \mathrm{RDF}$ and Azospirillum $+\mathrm{PSB}+$ $\mathrm{FYM}+50 \%$ RDF was significantly associated with growth, flowering and yield parameters of China aster. Organic manures and bio-fertilizers enhanced the growth, flowering and yield parameters of China aster as compared to inorganic used.

\section{References}

Ali T, Rashid H, Ajmal B, Sajjad R, and Ahmad N 2014. Investigation of biofertilizers influence on vegetative growth, flower quality, bulb yield and nutrient uptake in gladiolus (Gladiolus grandiflorus L.). Int. J. Plant Animal Environ. Sci. 4(1): 94-99.

Barad AV, Bhosale N and Mehta P 2015. Effect of nitrogen levels and cuttings (main and ratoon) on growth and flowering of golden rod (Solidago canadensis L.) during summer and rainy season planting. Hort. Flora Res. Spectrum 4(3): 230-235.

Bohra M, Khanna PR, Punetha P and Nautiyal BP 2016. Studies on the effect of organic manures and PSB on vegetative and floral parameters of China aster (Callistephus chinensis L. Ness.) cv. kamini under mid hills region of Himalaya. Bioscan. 11(4): 2707-2710. 
Dalve PD, Mane SV and Nimbalkar RR 2009. Effect of biofertilizers on growth, flowering and yield of gladiolus. Asian J. Hort. 4(1): 227-229.

Deshmukh PG, Khiratkar SD, Badge SA and Bhongle SA 2008. Effect of bioinoculants with graded doses of NPK on growth and yield of gaillardia. J. Soils Crops. 18(1): 212-216.

Hadwani MK, Varu DK, Panjiar N, Babariya VJ 2013. Effect of integrated nutrient management on growth, yield and quality of ratoon tuberose (Polianthus tuborosa L.) cv. Double. Asian J. Hort. 8(2): 448-451.

Keisam P, Manivannan K and Kumar S R 2014. Effect of organic nutrients on growth, flowering and yield of gladiolus (Gladiolus grandiflorus L.). Asian J. Hort. 9(2): 416-420.

Kumar S and Sharma S 2013. Effect of organic manure, drying methods on flower yield and carotenoid contents in marigold (Tagetes erecta L.). Asian J. Hort. 8(2): 385-90.

Kumar S, Dewan N, Nongrum HB and Marwein B 2016. Effect of nitrogen on growth, flowering and quality of China aster (Callistephus chinensis) cv. kamini. Curr. Hort. 4(2): 25-29

Kumar S, Momin BC and Dewan N 2015. Response of nutrition on growth and flowering of Dendrobium orchids under eastern Himalayan region. Hort. Flora Res. Spectrum. 4(3): 214-219.

Kumari A, Goyal RK, Choudhary M and Sindhu SS 2014. Effect of different nitrogen levels and biofertilizers on growth, yield and nutrient content of chrysanthemum. Ann. Agric. Res. 35(2): 156-163.

Lolasuramath GB 2014. Effect of NPK and biofertilizers on growth, yield and quality of china aster (Callistephus chinensis (L.) Nees) cv. Poornima for cut flower purpose. M.Sc. (Ag.) thesis, University of Horticultural Sciences, Bagalkot, India.

Panchal R V, Parekh NS, Parmar AB and Patel HC 2010. Effect of biofertilizers and nitrogenous fertilizer on growth, flowering and yield of annual white chrysanthemum (Chrysanthemum coronarium L.) under middle Gujarat agroclimatic conditions. Asian J. Hort. 5(1): 22-25.

Pandey G, Kumar S and Kumar A 2010. Effect of integrated nutrient management on growth and flowering of chrysanthemum (Dendranthema grandiflora). J. Orn. Hort. 13(2): 112-116.

Panse VG and Sukhatme PV 1995. Statistical methods for agricultural workers, Indian Council of Agricultural Research, New Delhi.

Ravindra SP, Hanumanthappa M, Hegde JN, Maheshwar KJ and Nagesha L 2013. Effect of integrated nutrient management on growth, yield and vase life of China aster (Callistephus chinensis L. Nees.) for coastal Karnataka. Environ. Ecol. 31(2): 1104-1106.

Sharma U, Chaudhary SVS and Chauhan J 2009. Effect of sources of applied nutrients on the growth, flowering and seed production of China aster under protected conditions. Haryana J. Hort. Sci. 38(3/4): 189-190.

Syamal M M, Dixit S K and Kumar S 2006. Effect of bio-fertilizers on growth and yield in marigold. J. Orn. Hort. 9(4): 304-305.

Thumar BV, Barad AV, Neelima P and Bhosale N 2013. Effect of integrated system of plant nutrition management on growth, yield and flower quality of African marigold (Tagetes erecta L.) cv. Pusa Narangi. Asian J. Hort. 8(2): 466-469.

Tomar KS, Kumar S, Shakywar RC and Pathak M 2013. Effect of spacing and nitrogen levels on growth, flowering and yield parameters of African marigold (Tagetes erecta L.) cv. Dwarf Orange. J. Orn. Hort. 16(1\&2): 70-74.

Zaredost F, Hashemabadi D, Ziyabari MB, Torkashvand AM, Kaviani B, Solimandarabi M J and Zarchini M 2014. The effect of phosphate bio-fertilizer (Barvar-2) on the growth of marigold. J. Environ. Bio. 35(2): 439-443.

(Manuscript received on 30 May, 2019; revised on 4 May, 2020) 